\title{
Knowing Puberty With E-Modules
}

\author{
Ketut Yuli Ayu Wulandari ${ }^{1 *}$, I Made Tegeh ${ }^{2 *}$, Ndara Tanggu Renda ${ }^{3 *}$ (iD \\ ${ }^{123}$ Pendidikan Guru Sekolah Dasar, Universitas Pendidikan Ganesha, Singaraja, Indonesia \\ *Corresponding author: okasatrawan26@gmail.com
}

\begin{abstract}
Abstrak
Guru masih kurang memanfaatkan media/bahan ajar saat mengajar, terutama pada pembelajaran daring. Sehingga guru masih kurang menggunakan media/bahan ajar yang inovatif dalam pembelajaran. Maka dari itu, penelitian ini bertujuan untuk mengembangkan e-modul pada pembelajaran IPA topik Masa Pubertas yang dilihat dari validitasnya. Jenis penelitian ini mengacu pada prosedur model pengembangan ADDIE yang terdiri dari tahap analisis, perancangan, pengembangan, implementasi, dan evaluasi. Pada penelitian ini tahap implementasi dan evaluasi tidak dilaksanakan karena saat ini masih dalam masa pandemi Covid-19 sehingga harus mematuhi protokol kesehatan. Subjek dalam penelitian ini adalah e-modul pada pembelajaran IPA topik Masa Pubertas dan ahli yang berkompeten pada bidangnya. Pengumpulan data dalam penelitian ini menggunakan metode kuesioner. Untuk mengetahui validitas e-modul, digunakan instrumen rating scale berupa lembar penilaian yang diberikan kepada dua ahli materi, dua ahli media, dan dua praktisi. Hasil uji validitas emodul IPA topik Masa Pubertas ini dihitung presentasenya dan dikonversikan ke dalam tabel pedoman skala lima. Berdasarkan e-modul yang dikembangkan, hasil uji validitas e-modul IPA dari ahli materi, ahli media, dan praktisi memperoleh kualifikasi sangat baik dan dinyatakan valid. Sehingga e-modul IPA topik Masa Pubertas ini cocok digunakan oleh guru saat mengajar karena e-modul ini memiliki tampilan yang menarik dan konten/isi dalam e-modul lengkap sehingga dapat menunjang aktivitas belajar siswa.
\end{abstract}

Kata kunci: E-Modul, IPA, Masa Pubertas

\begin{abstract}
Teachers still do not use media/teaching materials when teaching, especially in online learning. So that teachers still do not use innovative media/teaching materials in learning. Therefore, this study aims to develop an e-module in science learning on Puberty as seen from its validity. This type of research refers to the ADDIE development model procedure that consists of the stages of analysis, design, development, implementation, and evaluation. In this study, the implementation and evaluation stages were not carried out because they are currently still in the Covid-19 pandemic period, so they must comply with health protocols. The subjects in this study were e-modules on science learning on Puberty and experts who were competent in their fields. This study used a questionnaire method in collecting data. A rating scale instrument was used in an assessment sheet for two material experts, two media experts, and two practitioners to determine e-module validity. The test results of the science e-module on the topic of Puberty were calculated and converted into a five-scale guideline table. Based on the developed e-module, the science e-module validity test results from material experts, media experts, and practitioners obtained very good qualifications and were declared valid. So that the science e-module on the topic of Puberty is suitable for use by teachers when teaching because this e-module has an attractive appearance and the content/content in the emodule is complete so that it can support student learning activities.
\end{abstract}

Keywords: E-Module, Natural Sciences, Puberty

\begin{tabular}{|c|c|c|}
\hline History: & & Publisher: Undiksha Press \\
\hline Received & : March 19, 2021 & Licensed: This work is licensed under \\
\hline Revised & : March 21, 2021 & a Creative Commons Attribution 3.0 License \\
\hline Accepted & : June 10, 2021 & (c) (†) ( \\
\hline Published & : July 25,2021 & $U \mathrm{EY} \mathrm{SA}_{\mathrm{SA}}$ \\
\hline
\end{tabular}

\section{Introduction}

Covid-19 is a new type of coronavirus that has spread throughout the world (Kardeş, 2021; Purnama et al., 2021; Stoecklin et al., 2020). This virus was first reported in Wuhan, China, by WHO on December 31, 2019. Not only in China. Indonesia is also one of the countries affected by Covid-19. President Jokowi confirmed this with Minister of Health Terawan Agus Putranto, who stated that two Indonesian citizens were infected with Covid-19 (Abidah et al., 2020; Simamora, 2020). The widespread of Covid-19 has forced the government to make policies for people to carry out activities from home to avoid crowds (Jogezai et al., 2021; Karasmanaki \& Tsantopoulos, 2021). This way is expected to break the 
chain of the spread of the Covid-19 virus. The government's decision to impose social restrictions to anticipate the spread of Covid-19 has also impacted people's lives (Atmojo \& Nugroho, 2020; Nambiar, 2020).

The Covid-19 pandemic has greatly affected the world order in all fields. Many changes and updates are implemented, and many new policies are made, including in education (Bahasoan et al., 2020; Wan Hassan et al., 2020). Educational activities are one of the most significant impacts of Covid-19. Not only in Indonesia, other parts of the world who have been exposed to Covid-19 also feel the same way (Storch et al., 2021). The widespread of this virus forced the government to close educational institutions such as schools to universities temporarily (Kadafi et al., 2021; Qazi et al., 2021). One of the changes in education during the Covid-19 pandemic is the process of acquiring knowledge. In connection with the closure of educational institutions, the government changed learning that previously had to come to school. Now learning can be done only at home (Dong et al., 2020; Yustina et al., 2020). In this regard, UNESCO supports the implementation of large-scale online learning programs to reach students remotely (Garad et al., 2021; Yu, 2021). The government provides a policy to close all educational institutions. It is done to prevent the spread of the Covid-19 virus (A. Cahyadi, 2020; Satyawan et al., 2021).

Online learning is something new in the learning process by utilizing electronic tools and the internet (Chang et al., 2020; Simamora, 2020). Online learning media commonly used when learning online are Google Classroom, Google Meet, Zoom, WhatsApp, Ruang Guru, Zenius, and Brainly (Al-Maroof \& Al-Emran, 2018; Mpungose, 2021; Ramkissoon et al., 2020). Online learning aims to help students learn through the use of technology by using computers or gadgets. The use of technology in learning requires students to have basic electronic devices (Albashtawi \& Al Bataineh, 2020; Setiawan et al., 2017). Online learning can be done with the help of learning resources such as pictures, animations, videos, audio in learning (Alimin \& Saad, 2019; Octaberlina \& Muslimin, 2020). This learning resource is the teacher's main capital in developing online learning. Teachers must be able to design and create interesting learning according to the needs and characteristics of students in elementary schools (Khalil, 2018; Permata \& Bhakti, 2020).

However, the reality is that online learning is less effective to do. The ineffectiveness of online learning can be seen in the research (Anugrahana, 2020; Windhiyana, 2020). One of the weaknesses of online learning is the lack of maximum student involvement (Aji, 2020; Dewi, 2020). In this case, student involvement is meant as in participating in online learning. Therefore, teachers need to innovate in facilitating students when studying in class or at home, especially during the current Covid-19 pandemic (Abidah et al., 2020; Shaik Alavudeen et al., 2021). However, based on the results of the questionnaire distribution, it was found that the teacher had not innovated in developing media and teaching materials in the learning process. In this regard, this impacts one of the subjects that emphasizes direct experience and prioritizes the development and process of skills, science subjects (Hairida, 2016; Lestari, 2020). In science subjects, some materials are less in-depth. It follows the results of distributing questionnaires when researching schools, which can be seen: (1) $57.1 \%$ of teachers stated that in learning, students only use student books (thematic books) provided, including the science content contained in the textbook. (2) $57.1 \%$ of teachers stated that the science content material in student books still lacked in-depth. (3) $85.7 \%$ of teachers stated that teachers in teaching had not used electronic books (e-modules). (4) 71,4\% of teachers stated that the science content material in student books needed to be developed.

Based on the questionnaire, it is clear that teachers have not used complete media and teaching materials to support student learning during the Covid-19 pandemic. It causes online learning to be less than optimal (Abror et al., 2020; Nonthamand, 2020). Teaching materials have an important role in supporting the effectiveness of learning (Fisnani et al., 2020; 
Hamdunah et al., 2016). The effectiveness of the intended learning, such as teaching materials, is useful to help educators in the learning process. Educators are preparing teaching materials used in the learning process to assist students in achieving optimal learning goals in the learning planning process (Logan et al., 2021; Puspoko Jati et al., 2019). In addition, teaching materials can be said to be practical if the teaching materials developed can make it easier for educators to teach and make it easier for students to understand the material (Istuningsih et al., 2018; Komikesari et al., 2020). Therefore, teachers must be able to package learning as attractively as possible and according to the characteristics and needs of students so that learning objectives can be achieved even though it is done online (Arsanti, 2018; Herawati \& Muhtadi, 2018; Rigianti, 2020).

Based on the problems obtained, it is necessary to consider limited media and teaching materials in the online learning process. One solution is to develop media or teaching materials supported by information and communication technology (e-modules). EModules are part of learning that utilizes information and communication technology such as computers/laptops, gadgets, etc. which transformed into an electronic form that specially designed to support student learning based on the speed of understanding of each student (Fisnani et al., 2020; Hamdunah et al., 2016). The Electronic Module is also one of the learning resources that contains materials, methods, limitations, and how to evaluate packaged systematically and attractively to achieve the desired competencies (Logan et al., 2021; Puspoko Jati et al., 2019). Online learning makes e-modules an independent learning tool. In addition, e-modules are learning resources that can be easily integrated into the curriculum to support better learning (Komikesari et al., 2020; Logan et al., 2021).

E-Module itself has advantages such as a communicative language and has a two-way nature (Aufa et al., 2021; Istuningsih et al., 2018). It is easier to access to make it easier for students to learn the material. Not only that, e-modules are arranged systematically and present material in detail and coherently, which includes material, audio, video, and quizzes/practice questions that make it easier for students to learn (Laili, 2019; Syahroni, 2016). In general, the print and electronic modules do not show any difference in development, but the difference can be seen in terms of physical presentation. The electronic module adapts the existing components in the print module (Dumitrescu et al., 2014; Noroozi \& Mulder, 2017). Compared to print modules, e-modules have the advantages of physical presentation: (1) e-modules can be displayed using electronic devices such as mobile phones, laptops, and computers; (2) It is more practical when used because they can be carried anywhere; (3) Low production costs because product files can be copied for reproduction; (4) Can be equipped with audio, animation, and video in its presentation; and (5) durable (Majid et al., 2012).

In connection with this, it is necessary to research the development of e-module teaching materials that involve students actively, creatively, and independently in the learning process to improve learning outcomes even though learning is carried out online (Silalahi, 2020; Triwahyuningtyas et al., 2020). The findings of previous research stated that e-module is innovative teaching or strategy to improve student learning success (Asrial et al., 2020b; Logan et al., 2021). In addition, research found e-module was proven to be effective in improving science learning outcomes (Dwi Lestari \& Putu Parmiti, 2020; Rasmussen et al., 2020). The findings of previous research stated that developing e-modules developed in digital simulation subjects are successfully applied and suitable for use in the learning process (Neppala et al., 2018; Sriyanti et al., 2021). The implementation and use of emodules were carried out well in the appropriate category and received a positive response from students (Asrial et al., 2020a; Herawati \& Muhtadi, 2018; Syahrial et al., 2019).

Judging from the results of research conducted by other researchers, it can be seen that e-modules are proven to be effective and innovative in use in the learning process. With 
the development of e-modules, the e-modules developed in this study are different from the previously developed e-modules. The difference in this e-module lies in the material taken, the science material on the topic of Puberty in elementary schools. In addition, another difference in this e-module lies in the content in the e-module. The content in this e-module is complete than other e-modules because it is equipped with audio, video, and quizzes that can be directly displayed and done in the e-module. This study aims to develop an e-module on science learning on Puberty as seen from its validity. With the development of this e-module, it is hoped that teachers can be helped in teaching in the classroom and create other innovative learning to improve the quality of the process and results in learning.

\section{Methods}

This type of research was research on the development of e-modules in science learning during Puberty using the ADDIE model development design. The ADDIE model consists of 5 stages: Analyze, Design, Development, Implementation, and Evaluation (R. A. H. Cahyadi, 2019). At this stage of the ADDIE model, two stages cannot be implemented, the implementation and evaluation stages. The two stages were not carried out because they are currently still in the pandemic period, so they must comply with health protocols related to Covid-19. (1) Analysis stage, this stage starts from needs analysis, student characteristics analysis, curriculum analysis, and e-module analysis. A needs analysis was done by distributing questionnaires to teachers. In this needs analysis, the emphasis was on teachers in teaching need, especially when students are encouraged to study at home independently, especially in science learning on Puberty. Analysis of student characteristics was carried out so that researchers know the condition of students (targets) in e-modules. Curriculum analysis was carried out by reviewing basic competencies and indicators in sixth-grade science learning obtained from the teacher's book. The analysis results were used as the basis for material development that will determine the material in the e-module to be developed. The e-module analysis was obtained from needs analysis, student characteristics analysis, and curriculum analysis. The analysis determined the limitations found in the field and then designed a good e-module development suitable for students' needs and characteristics. (2) The design stage was carried out after the analysis stage is complete. The design begins with determining the entire e-module, starting from the front and back cover designs, compiling the material in the e-module, to make evaluation questions/quizzes. In the design process, this e-module uses Canva and Flipbuilder application programs. The e-module design completed was consulted with the supervisor to get suggestions or input to make improvements. (3) The development stage was carried out by developing an e-module according to the supervisor's input and suggestions. After the development of the e-module product was complete, the validity test of the developed media was carried out. The validity test was obtained from the reviews of each expert, material experts, media experts, and practitioners. The data from the expert reviews were analyzed and revised according to the input and suggestions from the experts.

The subjects in this research were e-module on science learning topics during Puberty and competent experts in their fields. These experts include two material experts who are competent in science, two media experts who will provide reviews of the products that have been developed, and practitioners who two sixth-grade teachers carry out. Data collection in this study used a questionnaire method to assess the feasibility of the e-module. The instrument used in this study was in the form of a Rating Scale. The rating scale was in the form of numbers. Assessment in the form of a rating scale from high to low or low to high. The rating scale in this study uses a scale of 5 - 1 (Ilhami \& Rimantho, 2017). 
The preparation of instruments was carried out to assess the products that have been developed. The instrument grid was first made to facilitate the instrument preparation. The science learning e-module instrument on the topic of Puberty for the feasibility test from material experts, media experts, and practitioners can be seen in the table.

Table 1. Material Expert Test Instruments

\begin{tabular}{|c|c|c|c|c|}
\hline No & Aspect & Indicator & Total & Number \\
\hline \multirow[t]{7}{*}{1} & Contents & $\begin{array}{l}\text { Compliance with the } \\
\text { basic competencies }\end{array}$ & 2 & 1,2 \\
\hline & & Clarity of purpose & 1 & 3 \\
\hline & & $\begin{array}{l}\text { Suitability to student } \\
\text { needs }\end{array}$ & 3 & $4,5,6$ \\
\hline & & $\begin{array}{l}\text { The truth of material } \\
\text { substance }\end{array}$ & 1 & 7 \\
\hline & & $\begin{array}{ll}\text { Image } & \text { illustration } \\
\text { suitability }\end{array}$ & 1 & 8 \\
\hline & & Video compatibility & 1 & 9 \\
\hline & & Quiz compatibility & 2 & 10,11 \\
\hline \multirow[t]{4}{*}{2} & Language & Readability & 2 & 12,13 \\
\hline & & clarity of information & 1 & 14 \\
\hline & & $\begin{array}{l}\text { Compliance with the } \\
\text { rules of Indonesian }\end{array}$ & 1 & 15 \\
\hline & & $\begin{array}{l}\text { Use language effectively } \\
\text { and efficiently }\end{array}$ & 1 & 16 \\
\hline \multirow[t]{2}{*}{3} & Presentation & $\begin{array}{l}\text { completeness } \\
\text { information }\end{array}$ & 1 & 17 \\
\hline & & Giving motivation & 2 & 18,19 \\
\hline
\end{tabular}

Table 2. Media Expert Test Instruments

\begin{tabular}{|c|c|c|c|c|}
\hline No & Aspect & Indicator & Total & Number \\
\hline \multirow[t]{4}{*}{1} & $\begin{array}{l}\text { Screen } \\
\text { display }\end{array}$ & $\begin{array}{l}\text { Composition of text and } \\
\text { background colors }\end{array}$ & 1 & 1 \\
\hline & & Layout & 2 & 2,3 \\
\hline & & Title clarity & 1 & 4 \\
\hline & & $\begin{array}{l}\text { the attractiveness of the } \\
\text { design }\end{array}$ & 1 & 5 \\
\hline 2 & Ease of use & Ease of operation & 2 & $6,7,8,9$ \\
\hline \multirow[t]{2}{*}{3} & Benefits & $\begin{array}{l}\text { Ease of teaching and } \\
\text { learning activities }\end{array}$ & 3 & $10,11,12$ \\
\hline & & $\begin{array}{l}\text { Attract students' } \\
\text { attention perhatian }\end{array}$ & 1 & 13 \\
\hline \multirow[t]{3}{*}{4} & Graphics & The use of color & 1 & 14 \\
\hline & & Use of letters & 2 & 15 \\
\hline & & Use of illustrations & 1 & 16 \\
\hline
\end{tabular}


Table 3. Practitioner Test Instruments

\begin{tabular}{|c|c|c|c|c|}
\hline No & Aspect & Indicator & Total & Number \\
\hline \multirow[t]{7}{*}{1} & \multirow[t]{7}{*}{$\begin{array}{l}\text { feasibility } \\
\text { Contents }\end{array}$} & $\begin{array}{l}\text { of Conformity with basic } \\
\text { competence }\end{array}$ & 1 & 1 \\
\hline & & Clarity of purpose & 2 & 2,3 \\
\hline & & Systematic presentation & 3 & 4 \\
\hline & & $\begin{array}{l}\text { completeness of } \\
\text { information }\end{array}$ & 1 & 5,6 \\
\hline & & Quiz compatibility & 1 & 7 \\
\hline & & $\begin{array}{l}\text { The truth of material } \\
\text { substance }\end{array}$ & 1 & 8 \\
\hline & & Video compatibility & 1 & 9 \\
\hline \multirow[t]{3}{*}{2} & \multirow[t]{3}{*}{ Language } & Readability & 2 & 10,11 \\
\hline & & clarity of information & 1 & 12 \\
\hline & & The use of language & 2 & 13,14 \\
\hline \multirow[t]{2}{*}{3} & \multirow[t]{2}{*}{ Benefits } & Ease of learning & 2 & 15,16 \\
\hline & & Ease of use of e-module & 1 & 17 \\
\hline \multirow[t]{2}{*}{4} & \multirow[t]{2}{*}{ Graphics } & Use of letters & 2 & 18 \\
\hline & & $\begin{array}{l}\text { The use of illustrations, } \\
\text { graphics, and images }\end{array}$ & 1 & 19 \\
\hline
\end{tabular}

The instrument that has been made must be tested for the validity of the instrument's content by experts (judges). The content validity test of this instrument uses the Gregory formula. The results of the validity test were entered in the $2 \times 2$ cross-tabulation .The questionnaires tested for validity were questionnaires from media experts, material experts, and practitioners. The content validity test results show that the validity of the assessment instrument for material experts, media experts, and practitioners is $=1.00$. Based on these results, the content validity of the e-module instrument on material experts, media experts, and practitioners shows that the instrument's content validity is in the very high validity category.

Data analysis methods and techniques used in this research are qualitative descriptive analysis and quantitative descriptive analysis. Qualitative data obtained from the review of material experts, media experts, and practitioners. Qualitative data presented in input, feedback, criticism, suggestions, or improvements from experts' reviews. At the same time, quantitative data obtained from the assessment results obtained from the e-module assessment sheet filled out by experts. This analysis data is used to process and analyze data in scores obtained from giving questionnaires in a descriptive percentage (Agung, 2014). A five-scale conversion determination can be used that can be seen in the following table.

Table 4. Conversion of achievement level with a scale of 5

\begin{tabular}{ccc}
\hline Achievement Level (\%) & Qualification & Description \\
\hline $90-100$ & Very good & No need to revise \\
$75-89$ & Good & Slightly revised \\
$65-74$ & Enough & Revised sufficiently \\
$55-64$ & Less & Many things need to be revised \\
$0-54$ & Bad & Re-product \\
\hline
\end{tabular}




\section{Results and Discussion Results}

The results of the development of the science e-module on the topic of Puberty through the ADDIE development stages consisted of the analysis, design, development, implementation, and evaluation stages. The analysis phase consists of needs analysis, student characteristics analysis, curriculum analysis, and e-module analysis. Analysis of student needs using a questionnaire instrument. This analysis emphasized knowing what teachers need in teaching, especially when students were encouraged to study at home independently. In addition, distributing this questionnaire aimed to determine the materials and teaching materials used in learning, especially online learning to suit competence demands. Based on the needs analysis, it was known that: (1) $57.1 \%$ of teachers stated that in learning students only used student books (thematic books) that had been provided, including the science content in the student books, (2) $57.1 \%$ of teachers stated that the science content material in student books is still not deep, (3) $85.7 \%$ of teachers stated that teachers in teaching had not used electronic books (e-modules), (4) $71.4 \%$ of teachers stated that science content material in student books need to be developed, such as some of the materials that exist during Puberty, the differences in the physical characteristics of men and women after Puberty and the process of menstruation. Based on this, the development of e-modules on science learning on the topic of Puberty was carried out.

Analysis of student characteristics was carried out so that researchers know the condition of students (targets). Based on the analysis results, it found that the characteristics of elementary school students are happy to learn using concrete media/teaching materials such as images, animations, audio, video, and so on. It is in line with Bujuri (2018) opinion, which states that in learning, it is necessary to give direct examples related to the object being studied because children aged 7-11 years are at the level of concrete thinking (real) or not abstract. Curriculum analysis is carried out by analyzing basic competencies and determining indicators on the science material on Puberty obtained from the teacher's book. The analysis results were used to determine the material on the media developed as the basis for material development. The results of the curriculum analysis are indicators consisting of five indicators. The five indicators are: 1) understanding the meaning of Puberty, 2) comparing the differences in the characteristics of childhood and Puberty, 3) comparing the differences in the physical characteristics of boys and girls after Puberty, 4) explaining the efforts and ways to maintain reproductive health during Puberty, and 5) explaining how to approach Puberty with confidence. Media analysis was carried out to find out the limitations found in the field. Then the analysis followed up by designing a good e-module development according to the needs and characteristics of students.

The design stage was carried out after the analysis stage was completed. The design begins with determining the entire e-module, starting from the front and back cover designs, compiling the material in the e-module, to make evaluation questions/quizzes. The science material developed is the topic of Puberty Period KD 3.2 Connecting the characteristics of Puberty in boys and girls with reproductive health. In the e-module, evaluation questions were designed in 5 essay questions and 20 objective questions for quizzes. In the design process, this e-module uses Canva and Flipbuilder application programs. The e-module design completed is then consulted with the supervisor to get suggestions or input to make improvements. After the media design improved, it proceeds to the development stage.

The development stage was carried out by developing a science e-module on the topic of Puberty following the input and suggestions of the supervisor. E-Module was developed with several parts, such as the beginning, core, and closing. The introduction contains a preface about the e-module, how to use it, and a table of contents. The core part of the emodule contains a material map that contains basic competencies and learning objectives and 
core material following the learning objectives. The final part of the e-module is in the form of a cover consist of a summary of the material, assignments, quizzes, bibliography, and biodata of the authors. The display of the E-Module on the topic of Puberty can be seen in Figure 1.
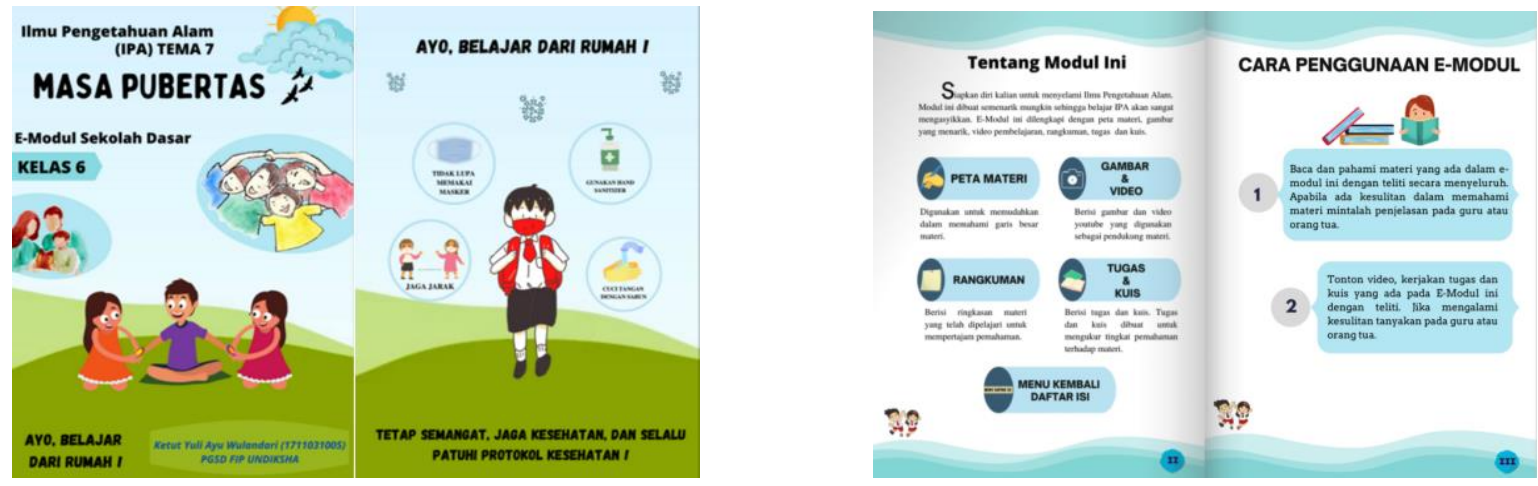

Figure 1. The Display E-Module

After the development of the e-module product is complete, the validity test of the developed media was carried out. The validity test was obtained from the reviews of each expert, two material experts, two media experts, and two practitioners (sixth-grade elementary school teachers). The results of the validity analysis with a percentage of $94.7 \%$ from first material experts and $96.8 \%$ from second material experts. So that the overall score percentage of the two material experts is $95.75 \%$, it can be seen that the validity results are in the percentage range of $90-100 \%$. Following the five-scale conversion guideline, the assessment of material experts on the science e-module on the topic of Puberty obtained very good qualifications.

The results of the validity analysis with a percentage of $93.75 \%$ from the first media expert and $92.5 \%$ from the second media expert. So that the overall score percentage of the two media experts is $93.125 \%$, it can be seen that the results of the validity of media experts are in the percentage range of $90-100 \%$. Following the five-scale conversion guidelines, the assessment of media experts on the science e-module on the topic of Puberty was very good. The validity analysis results with $96.8 \%$ from the first practitioner and $96.8 \%$ from the second practitioner. So that the overall score percentage of the two practitioners is $96.8 \%$, it can be seen that the results of the practitioner's validity are in the percentage range of 90 $100 \%$. Following the five-scale conversion guideline, the practitioner's assessment of the science e-module on the topic of Puberty received very good qualifications.

\section{Discussion}

The development of the science e-module on Puberty was very good because the content in the e-module has met all aspects of the assessment. In terms of material, e-modules have been developed based on the analysis of student needs and basic competencies. In addition, the material in the e-module follows learning objectives, clarity of learning objectives, the correctness of concepts, and good presentation of material. Clear learning objectives will be a reference in every learning process (Resita \& Ertikanto, 2018; Setiyani et al., 2020). Learning objectives are a very important factor in the learning process (Astra et al., 2020; Hamid et al., 2021). With a goal, the teacher has guidelines and targets to be achieved in teaching activities. If the learning objectives are clear, the learning activities in the classroom will be more focused (Liu et al., 2021; Pane \& Darwis Dasopang, 2017). 
E-Module on the topic of Puberty also has advantages in terms of visual appeal, which presents the material in the form of text, images, and videos. It is following the characteristics of students who are still at the concrete operational stage. It means that in learning, it is necessary to give direct examples related to the object being studied because the abilities of elementary-age children (7-11 years) are at the level of concrete thinking (real) or not abstract (Bujuri, 2018; Nurlaily et al., 2019). Therefore, elementary school children in learning must be supported by technological developments such as videos, animations, images on e-modules to make the learning process more innovative (Fisnani et al., 2020; Logan et al., 2021). The use of content visualization in e-modules, such as animations with text or images with text is very important to use (Komikesari et al., 2020; Raharjo et al., 2017). The use of this visualization aims to make users understand the content presented in the e-module. So with that e-module is one of the good media for elementary school age children (Aufa et al., 2021; Istuningsih et al., 2018). Therefore, the analysis of emodules is carried out in order to find out which e-modules are good according to the needs and characteristics of students.

The science e-module on Puberty has fulfilled all the elements in the design of the learning message. (1) Cover, the cover developed based on a textbook message design analysis, including aspects of writing. Writing the title on the cover of the e-module is made using larger font size and a firm typeface. Font sizes for children are usually larger than for teens or adults. Therefore, the text presented in this e-module uses a font size of 14 points. The good font size is not smaller than 10 points for easy reading by students (Nisa et al., 2020). (2) Instructions for using e-modules are packaged systematically, with instructions for using e-modules that will certainly make it easier to use so that students easily understand it (Sadimin Sadimin et al., 2017; Subarkah et al., 2021). (3) The basic competencies achieved in this section, the e-module describes the basic competencies that exist in the subjects in the emodule. (4) Learning objectives, learning objectives in e-modules arranged systematically using the ABCD formula (audience, behavior, condition, and degree). (5) The e-module material, in this section, is the content of the e-module material that was developed based on the characteristics of students. The content in the e-module uses multimedia elements such as text, images, audio/music, and video; (6) Summary presentation. Summaries are presented in e-modules to make it easier for readers to understand the material studied previously. The summary will help the reader to understand the structure of the text and re-access the content of the text; (7) Formative tests, formative tests are presented to remember the role of emodules as independent teaching materials. In this regard, an online quiz presented in twenty multiple-choice questions and five essay questions for evaluation. The presentation of formative tests on e-modules expected to measure the knowledge or competencies possessed by students. (8) The assessment section is the most important part of the e-module because it follows the role of the e-module, that is to expect direct feedback. This systematically designed online quiz is expected to provide feedback directly after students answer the quiz in e-modules. That way, students will know how far their ability to understand the material in the e-module.

This E-Module on the topic of Puberty has also developed following technological developments. The use of e-modules with digital technology is an innovation. The more technology media, the more choices of media that can be used anywhere and anytime online (Chen \& Li, 2011; Weng \& Chen, 2020). Technology in learning has good potential to support academic learning anytime and anywhere. So the use of technology in education concerns how we can use technology to support the learning process to obtain maximum results (Nurtanto et al., 2020; Zhang et al., 2021). Therefore, the more technology used, the more efficient it will be and achieve the maximum score (Lin, 2019; Mayer, 2020; Thomassen, 2020). 
Previous research stated that e-modules have succeeded in improving student learning outcomes and are suitable for use as technology-based teaching materials (Aprilia \& Suryadarma, 2020; Asmi et al., 2018). The same research shows that web-based e-modules can learn multimedia and improve student competency achievement (Hamzah \& Mentari, 2017; Sofyan et al., 2019). Other research results stated that the resulting e-module is included in the good and feasible criteria to use (Syahrial et al., 2019). Students are interested in learning to use e-modules. It can be seen from the results of the motivation questionnaire, which shows that students' motivation in learning to use e-modules included in the good category. Active learning refers to student behavior that involves students actively participating and contributing to the learning process (Wang, 2020).

Judging from the results of research that other researchers have done, the e-module on science learning on Puberty believed to be very good and feasible to be applied in the learning process. This science e-module can help teachers and students in the learning process, especially when learning online. In addition, this e-module will make it easier for students to learn so that online learning becomes more meaningful and learning objectives achieved properly. In this study, it was only limited to validity results. At the same time, practicality and effectiveness were not investigated due to the Covid-19 pandemic, so research could only be carried out until the development stage. Therefore, to find out more about the practicality and effectiveness of e-module development, it is hoped that other researchers can continue this research at the implementation and evaluation stage through experimental research.

\section{Conclusion}

The e-module teaching materials for science subjects on Puberty, developed using the ADDIE model as a whole, were valid with very good qualifications. The content in the emodule is interesting and complete (there are pictures, audio, video, and quizzes) so that it can be used by teachers to support student learning activities and can be used as an alternative for students to study independently at home.

\section{References}

Abidah, A., Hidaayatullaah, H. N., Simamora, R. M., Fehabutar, D., \& Mutakinati, L. (2020). The Impact of Covid-19 to Indonesian Education and Its Relation to the Philosophy of "Merdeka Belajar." Studies in Philosophy of Science and Education, 1(1), 38-49. https://doi.org/10.46627/sipose.v1i1.9

Abror, M., Suryani, N., \& Ardianto, D. T. (2020). Digital Flipbook Empowerment as A Development Means for History Learning Media. JPI (Jurnal Pendidikan Indonesia), 8(2), 266. https://doi.org/10.23887/jpi-undiksha.v8i2.24122

Agung, A. A. G. (2014). Metodologi Penelitian Pendidikan. Aditya Media Publish.

Aji, R. H. S. (2020). Dampak Covid-19 pada Pendidikan di Indonesia: Sekolah, Keterampilan, dan Proses Pembelajaran $\square$ Dampak Covid-19 pada Pendidikan di Indonesia: Sekolah, Keterampilan, dan Proses Pembelajaran. Jurnal Sosial \& Budaya Syar-I, 5(1), 395-402. https://doi.org/10.15408/sjsbs.v7i5.15314

Al-Maroof, R. A. S., \& Al-Emran, M. (2018). Students Acceptance of Google Classroom: An Exploratory Study using PLS-SEM Approach. International Journal of Emerging $\begin{array}{llll}\text { Technologies in Learning 112-123. } & \text { (IJET), }\end{array}$ https://doi.org/10.3991/ijet.v13i06.8275

Albashtawi, A. H., \& Al Bataineh, K. B. (2020). The effectiveness of google classroom among EFL students in Jordan: An innovative teaching and learning online platform. International Journal of Emerging Technologies in Learning, 15(11), 78-88. 
https://doi.org/10.3991/IJET.V15I11.12865

Alimin, F. G., \& Saad, M. S. M. (2019). The Effectiveness of Google Classroom as an Instructional Media: A Case of State Islamic Institute of Kendari, Indonesia. Journal of Humanities and Social Sciences, 7(2). https://doi.org/10/18510/hssr.2019.7227

Anugrahana, A. (2020). Hambatan, Solusi dan Harapan : Pembelajaran Daring Selama Masa Pandemi Covid-19 Oleh Guru Sekolah Dasar. Scholaria: Jurnal Pendidikan Dan Kebudayaan, 10(3), 282-289. https://doi.org/10.24246/j.js.2020.v10.i3.p282-289

Aprilia, I., \& Suryadarma, I. G. P. (2020). E-Module of Mangrove Ecosystem (EMME): Development, Validation, and Effectiveness in Improving Students' Self-Regulated. Biosfer: Jurnal Pendidikan, 13(1), 114-129. https://doi.org/10.21009/biosferjpb.v13n1.114-129

Arsanti, M. (2018). Pengembangan Bahan Ajar Mata Kuliah Penulisan Kreatif Bermuatan Nilai-Nilai Pendidikan Karakter Religius Bagi Mahasiswa Prodi Pbsi, Fkip, Unissula. KREDO : Jurnal Ilmiah Bahasa Dan Sastra, 1(2), 71-90. https://doi.org/10.24176/kredo.v1i2.2107

Asmi, A. R., Dhita Surbakti, A. N., \& C., H. (2018). E-Module Development Based Flip Book Maker For Character Building In Pancasila Coursework Sriwijaya University. Jurnal Pendidikan Ilmu Sosial, 27(1), 1-10. https://doi.org/10.17509/jpis.v27i1.9395

Asrial, Syahrial, Maison, Kurniawan, D. A., \& Piyana, S. O. (2020a). Ethnoconstructivism EModule to Improve Perception, Interest, and Motivation of Students in Class V Elementary School. JPI (Jurnal Pendidikan Indonesia), 9(1), 30-41. https://doi.org/10.23887/jpi-undiksha.v9i1.19222

Asrial, Syahrial, Maison, M., Kurniawan, D. A., \& Piyana, S. O. (2020b). Ethnoconstructivism E-Module to Improve Perception, Interest, And Motivation of Students in Class V Elementary School. Jurnal Pendidikan Indonesia, 9(1), 30-41. https://doi.org/10.23887/jpi-undiksha.v9i1.19222

Astra, I. M., Raihanati, R., \& Mujayanah, N. (2020). Development of Electronic Module Using Creative Problem-Solving Model Equipped with Hots Problems on The Kinetic Theory of Gases Material. Jurnal Penelitian \& Pengembangan Pendidikan Fisika, 6(2), 181-194. https://doi.org/10.21009/1.06205

Atmojo, A. E. P., \& Nugroho, A. (2020). EFL classes must go online! Teaching activities and challenges during COVID-19 pandemic in Indonesia. Register Journal, 13(1), 49-76. https://doi.org/10.18326/rgt.v13i1.49-76

Aufa, M. N., Rusmansyah, R., Hasbie, M., Jaidie, A., \& Yunita, A. (2021). The Effect of Using e-module Model Problem Based Learning (PBL) Based on Wetland Environment on Critical Thinking Skills and Environmental Care Attitudes. Jurnal Penelitian Pendidikan IPA, 7(3), 401-407. https://doi.org/10.29303/jppipa.v7i3.732

Bahasoan, A., Ayuandiani, W., Mukhram, M., \& Rahmat, A. (2020). Effectiveness of Online Learning In Pandemic Covid-19. Jurnal Kajian Pendidikan Dan Hasil Penelitian, 6(3), 100-106. https://doi.org/10.46729/ijstm.v1i2.30

Bujuri, D. A. (2018). Analisis Perkembangan Kognitif Anak Usia Dasar dan Implikasinya dalam Kegiatan Belajar Mengajar. LITERASI (Jurnal Ilmu Pendidikan), 9(1), 37. https://doi.org/10.21927/literasi.2018.9(1).37-50

Cahyadi, A. (2020). Covid-19 Outbreak and New Normal Teaching in Higher Education: Empirical Resolve from Islamic Universities in Indonesia. Dinamika Ilmu, 20(2), 255266. https://doi.org/10.21093/di.v20i2.2545

Cahyadi, R. A. H. (2019). Pengembangan Bahan Ajar Berbasis Addie Model. Halaqa: Islamic Education Journal, 3(1), 35. https://doi.org/10.21070/halaqa.v3i1.2124

Chang, T. Y., Hong, G., Paganelli, C., Phantumvanit, P., Chang, W. J., Shieh, Y. S., \& Hsu, M. L. (2020). Innovation of dental education during COVID-19 pandemic. Journal of 
Dental Sciences, 155. https://doi.org/10.1016/j.jds.2020.07.011

Chen, E., \& Li, Z. (2011). On the application of multimedia technology in foreign language teaching and learning in China's colleges: Challenges, problems and implications. 2011 International Conference on Multimedia Technology, ICMT 2011, 595-597. https://doi.org/10.1109/ICMT.2011.6001903

Dewi, W. A. F. (2020). Dampak COVID-19 terhadap Implementasi Pembelajaran Daring di Sekolah Dasar. Edukatif: Jurnal Ilmu Pendidikan, 2(1), 55-61. https://doi.org/10.31004/edukatif.v2i1.89

Dong, C., Cao, S., \& Li, H. (2020). Young children's online learning during COVID-19 pandemic: Chinese parents' beliefs and attitudes. Children and Youth Services Review, 118(June), 105440. https://doi.org/10.1016/j.childyouth.2020.105440

Dumitrescu, C., Olteanu, R. L., Gorghiu, L. M., \& Gorghiu, G. (2014). Learning Chemistry in the Frame of Integrated Science Modules - Romanian Student's Perception. Procedia - Social and Behavioral Sciences, 116(September 2015), 2516-2520. https://doi.org/10.1016/j.sbspro.2014.01.603

Dwi Lestari, H., \& Putu Parmiti, D. P. P. (2020). Pengembangan E-Modul Ipa Bermuatan Tes Online Untuk Meningkatkan Hasil Belajar. Journal of Education Technology, 4(1), 73. https://doi.org/10.23887/jet.v4i1.24095

Fisnani, Y., Utanto, Y., \& Ahmadi, F. (2020). The Development of E-Module for Batik Local Content in Pekalongan Elementary School. Innovative Journal of Curriculum and Educational Technology, 9(1), 40-47. https://doi.org/10.15294/IJCET.V9I1.35592

Garad, A., Al-Ansi, A. M., \& Qamari, I. N. (2021). The Role Of E-Learning Infrastructure And Cognitive Competence In Distance Learning Effectiveness During The Covid-19 Pandemic. Cakrawala Pendidikan, 40(1). https://doi.org/10.21831/cp.v40i1.33474

Hairida, H. (2016). The effectiveness using inquiry based natural science module with authentic assessment to improve the critical thinking and inquiry skills of junior high school students. Jurnal Pendidikan IPA Indonesia, 5(2), 209-215. https://doi.org/10.15294/jpii.v5i2.7681

Hamdunah, Yunita, A., Zulkardi, \& Muhafzan. (2016). Development a Constructivist Module and Web on Circle and Sphere Material with Wingeom Software. Journal on Mathematics Education, 7(2), 109-116. https://doi.org/10.22342/jme.7.2.3536.109-116

Hamid, S. N. M., Lee, T. T., Taha, H., Rahim, N. A., \& Sharif, A. M. (2021). E-Content Module For Chemistry Massive Open Online Course (Mooc): Development And Students' Perceptions. Journal of Technology and Science Education, 11(1), 67-92. https://doi.org/10.3926/jotse.1074

Hamzah, I., \& Mentari, S. (2017). Development of Accounting E-Module to Support the Scientific Approach of Students Grade X Vocational High School. Journal of Accounting and Business Education, 1(1), 78. https://doi.org/10.26675/jabe.v1i1.9751

Herawati, N. S., \& Muhtadi, A. (2018). Pengembangan Modul Elektronik (E-Modul) Interaktif Pada Mata Pelajaran Kimia kelas XI SMA. Jurnal Inovasi Teknologi Pendidikan, 5(2), 180-191. https://doi.org/10.21831/jitp.v5i2.15424

Ilhami, R. S., \& Rimantho, D. (2017). Penilaian Kinerja Karyawan dengan Metode AHP dan Rating Scale. Jurnal Optimasi Sistem Industri, 16(2). https://doi.org/10.25077/josi.v16.n2.p150-157.2017

Istuningsih, W., Baedhowi, B., \& Sangka, K. B. (2018). The effectiveness of scientific approach using e-module based on learning cycle 7e to improve students' learning outcome. International Journal of Educational Research Review, 3(3). https://doi.org/10.24331/ijere.449313

Jogezai, N. A., Baloch, F. A., Jaffar, M., Shah, T., Khilji, G. K., \& Bashir, S. (2021). Teachers' Attitudes Towards Social Media (SM) Use in Online Learning Amid The 
COVID-19 Pandemic: The Effects of SM Use by Teachers and Religious Scholars During Physical Distancing. Journal Heliyon, 7(4), 1-9. https://doi.org/10.1016/j.heliyon.2021.e06781

Kadafi, A., Alfaiz, A., Ramli, M., Asri, D. N., \& Finayanti, J. (2021). The impact of islamic counseling intervention towards students' mindfulness and anxiety during the covid-19 pandemic. Islamic Guidance and Counseling Journal, 4(1), 55-66. https://doi.org/10.25217/igcj.v4i1.1018

Karasmanaki, E., \& Tsantopoulos, G. (2021). Impacts of social distancing during COVID-19 pandemic on the daily life of forestry students. Children and Youth Services Review, 120(December 2020), 105781. https://doi.org/10.1016/j.childyouth.2020.105781

Kardeş, S. (2021). Public interest in spa therapy during the COVID-19 pandemic: analysis of Google Trends data among Turkey. International Journal of Biometeorology, 65(6), 945-950. https://doi.org/10.1007/s00484-021-02077-1

Khalil, Z. M. (2018). EFL Students' Perceptions towards Using Google Docs and Google Classroom as Online Collaborative Tools in Learning Grammar. Applied Linguistics Research Journal, 2(2), 33-48. https://doi.org/10.14744/alrj.2018.47955

Komikesari, H., Mutoharoh, M., Dewi, P. S., Utami, G. N., Anggraini, W., \& Himmah, E. F. (2020). Development of e-module using flip pdf professional on temperature and heat material. Journal of Physics: Conference Series, 1572(1). https://doi.org/10.1088/17426596/1572/1/012017

Laili, I. (2019). Efektivitas Pengembangan E-Modul Project Based Learning Pada Mata Pelajaran Instalasi. Jurnal Imiah Pendidikan Dan Pembelajaran, 3, 306-315. https://doi.org/10.23887/jipp.v3i3.21840. 306-309

Lestari, H. (2020). Literasi Sains Siswa Melalui Penerapan Model Pembelajaran Blended Learning Dengan Blog. Naturalistic: Jurnal Kajian Penelitian Pendidikan Dan Pembelajaran. https://doi.org/10.35568/naturalistic.v4i2b.769

Lin, P. H., Su, Y. N., \& Huang, Y. M. (2019). Evaluating reading fluency behavior via reading rates of elementary school students reading e-books. Computers in Human Behavior, 100, 258-265. https://doi.org/10.1016/j.chb.2018.10.004

Liu, X., Kong, J., Jiang, M., \& Li, S. (2021). Interactive information module for person reidentification. Journal of Visual Communication and Image Representation, 75. https://doi.org/10.1016/j.jvcir.2021.103033

Logan, R. M., Johnson, C. E., \& Worsham, J. W. (2021). Development of an E-learning Module to Facilitate Student Learning and Outcomes. Teaching and Learning in Nursing, 16(2), 139-142. https://doi.org/10.1016/j.teln.2020.10.007

Majid, M. S. Z. B. A., Ali, M. M. B. A., Rahim, A. A. B. A., \& Khamis, N. Y. B. (2012). The Development of Technical English Multimedia Interactive Module to Enhance Student Centered Learning (SCL). Procedia - Social and Behavioral Sciences, 67, 345-348. https://doi.org/10.1016/j.sbspro.2012.11.337

Mayer, R. E. (2020). Where is the learning in mobile technologies for learning? $\begin{array}{llll}\text { Contemporary Educational } & \text { Psychology, } & 60, & 101824 .\end{array}$ https://doi.org/10.1016/j.cedpsych.2019.101824

Mpungose, C. B. (2021). Lecturers' reflections on use of Zoom video conferencing technology for e-learning at a South African university in the context of coronavirus. African Identities. https://doi.org/10.1080/14725843.2021.1902268

Nambiar, D. (2020). The impact of online learning during COVID-19: students ' and teachers ' perspective. The International Journal of Indian Psychology, 8(2), 783-793. https://doi.org/10.25215/0802.094

Neppala, P., Sherer, M. V., Larson, G., Bryant, A. K., Panjwani, N., Murphy, J. D., \& Gillespie, E. F. (2018). An Interactive Contouring Module Improves Engagement and 
Interest in Radiation Oncology Among Preclinical Medical Students: Results of a Randomized Trial. Practical Radiation Oncology, 8(4), e190-e198. https://doi.org/10.1016/j.prro.2018.01.001

Nisa, W. L., Ismet, I., \& Andriani, N. (2020). Development of E-Modules Based on Multirepresentations in Solid-State Physics Introductory Subject. Berkala Ilmiah Pendidikan Fisika, 8(2), 73. https://doi.org/10.20527/bipf.v8i1.7690

Nonthamand, N. (2020). Guideline to develop an instructional design model using video conference in open learning. International Journal of Emerging Technologies in Learning, 15(3), 140-155. https://doi.org/10.3991/ijet.v15i03.10842

Noroozi, O., \& Mulder, M. (2017). Design and Evaluation of a Digital Module with Guided Peer Feedback for Student Learning Biotechnology and Molecular LifeSciences, Attitudinal Change, and Satisfaction. Biochemistry and Molecular Biology Education, 45(1), 31-39. https://doi.org/10.1002/bmb.20981

Nurlaily, V. A., Soegiyanto, H., \& Usodo, B. (2019). Elementary school teacher's obstacles in the implementation of problem-based learning model in mathematics learning. Journal on Mathematics Education, 10(2), 229-238. https://doi.org/10.22342/jme.10.2.5386.229-238

Nurtanto, M., Sofyan, H., Pardjono, P., \& Suyitno, S. (2020). Development model for competency improvement and national vocational qualification support frames in automotive technology. International Journal of Evaluation and Research in Education, 9(1), 168-176. https://doi.org/10.11591/ijere.v9i1.20447

Octaberlina, L. R., \& Muslimin, A. I. (2020). EFL Students Perspective towards Online Learning Barriers and Alternatives Using Moodle / Google Classroom during COVID19 Pandemic. International Journal of Higher Education, 9(6), 1-9. https://doi.org/10.5430/ijhe.v9n6p1

Pane, A., \& Darwis Dasopang, M. (2017). Belajar Dan Pembelajaran. FITRAH:Jurnal Kajian Ilmu-Ilmu Keislaman, 3(2), 333. https://doi.org/10.24952/fitrah.v3i2.945

Permata, A., \& Bhakti, Y. B. (2020). Keefektifan Virtual Class dengan Google Classroom dalam Pembelajaran Fisika Dimasa Pandemi Covid-19. JIPFRI (Jurnal Inovasi Pendidikan Fisika Dan Riset Ilmiah), 4(1), 27-33. https://doi.org/10.30599/jipfri.v4i1.669

Purnama, S., Ulfah, M., Machali, I., Wibowo, A., \& Narmaditya, B. S. (2021). Does digital literacy influence students' online risk? Evidence from Covid-19. Heliyon, 7(6). https://doi.org/10.1016/j.heliyon.2021.e07406

Puspoko Jati, D. H., Ismanto, B., \& Sulasmono, B. S. (2019). The Development of Local Wisdom Based Character Education Training Module. Journal of Education Research and Evaluation, 3(1), 1-9. https://doi.org/10.23887/jere.v3i1.17763

Qazi, A., Qazi, J., Naseer, K., Zeeshan, M., Qazi, S., Abayomi-alli, O., Ahmad, I. S., Darwich, M., Talpur, A., Hardaker, G., Naseem, U., Yang, S., \& Haruna, K. (2021). Adaption of Distance Learning to Continue the Academic Year Amid COVID-19 Lockdown. Journal Pre-Proofs (Children and Youth Services Review), 1-20. https://doi.org/10.1016/j.childyouth.2021.106038

Raharjo, M. W. C., Suryati, S., \& Khery, Y. (2017). Pengembangan E-Modul Interaktif Menggunakan Adobe Flash Pada Materi Ikatan Kimia Untuk Mendorong Literasi Sains Siswa. Hydrogen: Jurnal Kependidikan Kimia, $5(1), \quad 8$. https://doi.org/10.33394/hjkk.v5i1.102

Ramkissoon, P., Belle, L. J., \& Bhurosy, T. (2020). Perceptions and experiences of students on the use of interactive online learning technologies in Mauritius. International Journal of Evaluation and Research in Education. https://doi.org/10.11591/ijere.v9i4.20692

Rasmussen, E., Goddard, A. G., \& Bayer, D. K. (2020). Use of electronic learning modules 
can improve medical trainee knowledge regarding anaphylaxis diagnosis and treatment. Annals of Allergy, Asthma \& Immunology, 124(3). https://doi.org/10.1016/j.anai.2019.12.018

Resita, I., \& Ertikanto, C. (2018). Designing electronic module based on learning content development system in fostering students' multi representation skills. Journal of Physics: Conference Series, 1022(1), 012025. https://doi.org/10.1088/17426596/1022/1/012025

Rigianti, H. A. (2020). Kendala Pembelajaran Daring Guru Sekolah Dasar di Kabupaten Banjarnegara. Orphanet Journal of Rare Diseases, 21(1), 1-9. https://doi.org/10.31316/esjurnal.v7i2.768

Sadimin Sadimin, Wahyu Hardyanto, \& Slamet, A. (2017). Developing An E-Module-Based Classroom Action Research Management Training Model For Teachers High School. International Journal of Education and Research, 5(2), 79-90. https://doi.org/10.15294/jed.v5i3.18123

Satyawan, I. M., Wahjoedi, W., \& Swadesi, I. K. I. (2021). The Effectiveness of Online Learning Through Undiksha E-Learning During the Covid-19 Pandemic. Journal Education Technology, 5(2). https://doi.org/10.23887/jet.v5i2.32364

Setiawan, Innatesari, D. K., Sabtiawan, W. B., \& Sudarmin, S. (2017). The development of local wisdom-based natural science module to improve science literation of students. Jurnal Pendidikan IPA Indonesia, 6(1), 49-54. https://doi.org/10.15294/jpii.v6i1.9595

Setiyani, Putri, D. P., Ferdianto, F., \& Fauji, S. H. (2020). Designing a Digital Teaching Module Based on Mathematical Communication in Relation and Function. Journal on Mathematics Education, 11(2), 223-236. https://doi.org/10.22342/jme.11.2.7320.223236

Shaik Alavudeen, S., Easwaran, V., Iqbal Mir, J., Shahrani, S. M., Ali Aseeri, A., Abdullah Khan, N., Mohammed Almodeer, A., \& Abdullah Asiri, A. (2021). The influence of COVID-19 related psychological and demographic variables on the effectiveness of elearning among health care students in the southern region of Saudi Arabia. Saudi Pharmaceutical Journal. https://doi.org/10.1016/j.jsps.2021.05.009

Silalahi, M. V. (2020). Development of E-Modules Based on Exe-Learning on Topics of Reaction Rate Against Student Learning Outcomes Mechanical Engineering. International Journal of Education and Curriculum Application, 3(2), 114-120. https://doi.org/10.31764/ijeca.v3i2.2672

Simamora, R. M. (2020). The Challenges of Online Learning during the COVID-19 Pandemic: An Essay Analysis of Performing Arts Education Students. Studies in Learning and Teaching, 1(2), 86-103. https://doi.org/10.46627/silet.v1i2.38

Sofyan, H., Anggereini, E., \& Saadiah, J. (2019). Development of E-Modules Based on Local Wisdom in Central Learning Model at Kindergartens in Jambi City. European Journal of Educational Research, 8(4), 1137-1143. https://doi.org/10.12973/eu-jer.8.4.1137

Sriyanti, I., Almafie, M. R., Marlina, L., \& Jauhari, J. (2021). The effect of Using FlipbookBased E-modules on Student Learning Outcomes. Kasuari: Physics Education Journal (KPEJ), 3(2), 69-75. https://doi.org/10.37891/kpej.v3i2.156

Stoecklin, S. B., Rolland, P., Silue, Y., Mailles, A., Campese, C., Simondon, A., Mechain, M., Meurice, L., Nguyen, M., Bassi, C., Yamani, E., Behillil, S., Ismael, S., Nguyen, D., Malvy, D., Lescure, F. X., Georges, S., Lazarus, C., Tabai, A., ... Levy-Bruhl, D. (2020). First cases of coronavirus disease 2019 (COVID-19) in France: Surveillance, investigations and control measures, January 2020. Eurosurveillance, 25(6), 2000094. https://doi.org/10.2807/1560-7917.ES.2020.25.6.2000094

Storch, E. A., Sheu, J. C., \& Guzick, A. G. et al. (2021). Impact of the COVID-19 pandemic on exposure and response prevention outcomes in adults and youth with obsessive- 
compulsive disorder. Psychiatry Research, 295(October 2020), 113597. https://doi.org/10.1016/j.psychres.2020.113597

Subarkah, C. Z., Alhak, A. A., Sari, S., Ruswandi, U., \& Rochman, C. (2021). Developing Emodule on the Topic of Integrated Addictive Substances with Islamic Values. JTK (Jurnal Tadris Kimiya), 6(1), 16-25. https://doi.org/10.15575/jtk.v6i1.9802

Syahrial, Asrial, Kurniawan, D. A., \& Piyana, S. O. (2019). E-Modul Etnokontruktivisme: Implementasi Pada Kelas V Sekolah Dasar Ditinjau Dari Persepsi, Minat Dan Motivasi. JTP - Jurnal Teknologi Pendidikan, 21(2), 165-177. https://doi.org/10.21009/jtp.v21i2.11030

Syahroni, M. W., Dewi, N. R., \& Kasmui. (2016). The Effect of Using Digimon (Science Digital Module) with Scientific Approach at the Visualization of Students' Independence and Learning Results. Jurnal Pendidikan IPA Indonesia, 5(1), 116-122. https://doi.org/10.15294/jpii.v5i1.5800

Thomassen, G., Van Passel, S., \& Dewulf, J. (2020). A review on learning effects in prospective technology assessment. Renewable and Sustainable Energy Reviews, 130(May), 109937. https://doi.org/10.1016/j.rser.2020.109937

Triwahyuningtyas, D., Ningtyas, A. S., \& Rahayu, S. (2020). The problem-based learning emodule of planes using Kvisoft Flipbook Maker for elementary school students. Jurnal Prima Edukasia, 8(2), 199-208. https://doi.org/10.21831/jpe.v8i2.34446

Wan Hassan, W. A. ., Ariffin, A., Ahmad, F., Sharber, S. N. ., Azizi, N., \& Zulkiflee, S. . (2020). COVID-19 Pandemic: Langkawi Vocational College Student Challenge in Using Google Classroom for Teaching and Learning ( $\mathrm{T} \& \mathrm{~L}$ ). International Journal of Advanced Trends in Computer Science and Engineering, 9(3), 3299-3307. https://doi.org/10.30534/ijatcse/2020/127932020

Wang, Y. H. (2020). Design-based research on integrating learning technology tools into higher education classes to achieve active learning. Computers and Education, 156(May), 103935. https://doi.org/10.1016/j.compedu.2020.103935

Weng, S. S., \& Chen, H. C. (2020). Exploring the role of deep learning technology in the sustainable development of the music production industry. Sustainability (Switzerland), 12(2), 1-20. https://doi.org/10.3390/su12020625

Windhiyana, E. (2020). Dampak Covid-19 Terhadap Kegiatan Pembelajaran Online Di Perguruan Tinggi Kristen Di Indonesia. Perspektif Ilmu Pendidikan, 34(1), 1-8. https://doi.org/10.21009/pip.341.1

Yu, Z. (2021). The effects of gender, educational level, and personality on online learning outcomes during the COVID-19 pandemic. International Journal of Educational Technology in Higher Education, 18(1), 1-17. https://doi.org/10.1186/s41239-02100252-3

Yustina, Syafii, W., \& Vebrianto, R. (2020). The effects of blended learning and projectbased learning on pre-service biology teachers' creative thinking skills through online learning in the COVID-19 pandemic. Jurnal Pendidikan IPA Indonesia, 9(3), 408-420. https://doi.org/10.15294/jpii.v9i3.24706

Zhang, H., Daim, T., \& Zhang, Y. (Peggy). (2021). Integrating patent analysis into technology roadmapping: A latent dirichlet allocation based technology assessment and roadmapping in the field of Blockchain. Technological Forecasting and Social Change, 167. https://doi.org/10.1016/j.techfore.2021.120729 